\title{
Characteristics of Rhizobium tianshanense sp. nov., a Moderately and Slowly Growing Root Nodule Bacterium Isolated from an Arid Saline Environment in Xinjiang, People's Republic of China
}

\author{
WENXIN CHEN*, ENTAO WANG, SUYING WANG, YINGBO LI, XIAOQIONG CHEN, AND YING LI \\ Department of Microbiology, Beijing Agricultural University, Beijing 100094, People's Republic of China
}

\begin{abstract}
We performed a numerical analysis of 148 phenotypic characteristics of 20 strains of root nodule bacteria isolated from an arid saline desert soil in the Xinjiang region of northwestern People's Republic of China and compared these organisms with 28 Rhizobium and Bradyrhizobium strains obtained from different regions of the People's Republic of China and from other countries, including nine type strains of different species. All of the strains examined clustered into two groups at a similarity level of more than $63 \%$. Group I included all of the previously described Rhizobium species and was divided into eight subgroups, which corresponded to previously described Rhizobium species, at a similarity level of more than $82 \%$. Group II was divided into the following three subgroups at a similarity level of more than $80 \%$ Bradyrhizobium japonicum, a cluster containing 17 moderately and slowly growing strains isolated in the Xinjiang region, and a small subgroup containing three fast-growing strains. The generation times of the moderately and slowly growing strains were 5 to $15 \mathrm{~h}$, and these organisms produced acid in medium containing mannitol. The DNA G+C contents of the members of this group ranged from 59 to 63 mol\%. DNA-DNA hybridization experiments revealed that the levels of DNA homology among all of the moderately and slowly growing strains obtained from Xinjiang were more than $70 \%$ and that the levels of DNA homology between representative strains of this group and the type strains of all previously described species of root- and stem-nodulating bacteria were low. All of our experimental data indicated that the moderately and slowly growing rhizobia isolated from Xinjiang are members of a new species. Partial 16S rRNA gene sequencing of the type strain. A-1BS (= CCBAU3306), and a comparison of the resulting sequence with the sequences of previously described species revealed that strain A-1BS is closely related to Rhizobium loti, Rhizobium huakuii, and Rhizobium galegae, but not to B. japonicum and Azorhizobium caulinodans. On the basis of our results, we propose that the strains which we studied are members of a new species, Rhizobium tianshanense. The type strain, A-1BS (= CCBAU3306), has been deposited in the Culture Collection of Beijing Agricultural University, Beijing, People's Republic of China.
\end{abstract}

At the present time, all bacteria that induce nodules on the roots of leguminous plants are assigned to three genera $(8,14)$. The genus Rhizobium comprises a group of fast growers and includes eight species, Rhizobium leguminosarum, Rhizobium meliloti, Rhizobium loti (14), Rhizobium fredii (20), Rhizobium huakuii (2), Rhizobium galegae (15), Rhizobium tropici (16), and Rhizobium etli (21). Each of these species is associated with a group of host plants and is distinguished from the other species mainly on the basis of DNA relatedness values, $16 \mathrm{~S}$ rRNA homology values, and some phenotypic characteristics. The genus Bradyrhizobium comprises a group of slow growers and contains one species, Bradyrhizobium japonicum, which induces nodules on a wide range of leguminous plants (14). The genus Azorhizobium contains one species, Azorhizobium caulinodans, which induces stem and root nodules on Sesbania rostrata, a tropical legume (8). In addition, some unique groups have been identified in numerical taxonomy and DNA relatedness studies. These groups include exceptionally slowly growing soybean rhizobia (personal communication) and groups of fast-growing rhizobia isolated from tropical regions (10).

Extensive studies on the phylogenetic relationships of rootand stem-nodulating bacteria in which workers have used $16 \mathrm{~S}$ rRNA (ribosomal DNA) sequencing or rRNA-DNA hybridization have revealed that all previously described rhizobia belong to the alpha subclass of the Proteobacteria $(7,12,13,19$,

* Corresponding author. Telex: 222487 BAU CN. Fax: 86-12582332 .
23, 25-30) and that both the genus Rhizobium and the genus Bradyrhizobium are much more closely related to their corresponding nonsymbiotic relatives than to each other. Several distinct lineages have been identified in the genus Rhizobium, including the $R$. leguminosarum- $R$. tropici lineage, the $R$. meliloti-R. fredii lineage, the $R$. huakuii- $R$. loti lineage, and the $R$. galegae lineage $(19,27)$. Considering the fact that Agrobacterium, Phyllobacterium, Mycoplana, Brucella, and Ochrobacterium species are embedded in Rhizobium lineages (19, 25-27), these Rhizobium lineages might represent separate genera (19, 25-30). The genus Bradyrhizobium constitutes a separate lineage and is closely related to Rhodopseudomonas palustris, Blastobacter denitrificans, and the genera Afipia, and $\mathrm{Ni}$ trobacter $(25,26)$. The genus Azorhizobium represents a separate lineage that is more closely related to the genus Bradyrhizobium than to the genus Rhizobium $(8,30)$.

Considering the results mentioned above and the fact that the symbionts that have been studied so far have come from only $15 \%$ of the 19,700 species of legumes (1), it is possible that more genera and species will be needed to accommodate all of the root- and stem-nodulating bacteria when additional symbioses are examined (28-30). The present classification of rhizobia is clearly an interim classification (11).

Since 1980 we have been surveying root nodule bacteria isolated from various species of legumes growing in the Xinjiang region of northwestern People's Republic of China, and we have classified a number of isolates by using numerical taxonomy (2). A dendrogram showed that the fast-growing rhizobia isolated from a number of common legumes (e.g., Vicia and Trifoloium species) growing in Xinjiang belong to 
TABLE 1. Strains of bacteria examined and their origins

\begin{tabular}{|c|c|c|c|}
\hline Strain & Host & Origin $^{a}$ & Source $^{b}$ \\
\hline \multicolumn{4}{|l|}{ R. loti strains } \\
\hline NZP2213 ${ }^{\mathrm{T}}(=\operatorname{ATCC} 33669)$ & Lotus corniculatus & & NZP \\
\hline NZP2227 & Lotus sp. & & NZP \\
\hline NZP2234 & Lotus sp. & & NZP \\
\hline \multicolumn{4}{|l|}{ R. meliloti strains } \\
\hline $\mathrm{H} 1$ & Melilotus albus & Heilongjiang & CCBAU \\
\hline USDA $1002^{T}$ & & United States & USDA \\
\hline $102 \mathrm{~F} 28$ & Medicago sativa & & CCBAU \\
\hline R. legunimosarum bv. viceae USDA $2370^{\mathrm{T}}$ & & United States & USDA \\
\hline R. leguminosarum bv. trifolii $162 \mathrm{~K} 68$ & Trifolium sp. & United States & USDA \\
\hline R. leguminosarum bv. phaseoli $127 \mathrm{~K} 17$ & Phaseolus sp. & United States & USDA \\
\hline \multicolumn{4}{|l|}{ R. tropici strains } \\
\hline BR853 & Leucaena leucocephala & & CNPBS \\
\hline CIAT $899^{\mathrm{T}}$ & Phaseolus vulgaris & & CNPBS \\
\hline C-05-I & Phaseolus vulgaris & & CNPBS \\
\hline \multicolumn{4}{|l|}{ R. galegae strains } \\
\hline HAMBI540 & Galega orientalis & Finland & HAMBI \\
\hline HAMBI1185 & Galega sp. & United States & HAMBI \\
\hline HAMBI503 & Galega sp. & United States & HAMBI \\
\hline \multicolumn{4}{|l|}{ R. huakuii strains } \\
\hline PL-52 & Astragalus sinicus & Hubei & CCBAU \\
\hline A106 & Astraglaus sinicus & Hubei & CCBAU \\
\hline CCBAU $2609^{\mathrm{T}}$ & Astragalus sinicus & Nanjing & CCBAU \\
\hline \multicolumn{4}{|l|}{ R. fredii strains } \\
\hline 2048 & Glycine soja & Liaoning & SFRI \\
\hline USDA194 & Glycine soja & Henan & USDA \\
\hline $\mathrm{USDA}^{205^{\mathrm{T}}}$ & Glycine soja & Henan & USDA \\
\hline \multicolumn{4}{|l|}{ Rhizobium sp. strains } \\
\hline CCBAU105 & Glycine $\max$ & Xinjiang & CCBAU \\
\hline CCBAU108 & Glycine $\max$ & Xinjiang & CCBAU \\
\hline CCBAU110 ${ }^{\mathrm{T}}$ & Glycine max & Xinjiang & CCBAU \\
\hline \multicolumn{4}{|l|}{ Bradyrhizobium japonicum strains } \\
\hline USDA6 $^{\mathrm{T}}$ & Glycine $\max$ & United States & USDA \\
\hline USDA110 & Glycine $\max$ & & USDA \\
\hline USDA2110 & Glycine $\max$ & United States & USDA \\
\hline USDA3045 & Lupinus sp. & United States & USDA \\
\hline \multicolumn{4}{|l|}{ R. tianshanense strains } \\
\hline A-1BS ${ }^{\mathrm{T}}$ & Glycyrrhiza pallidiflora & Xinjiang & CCBAU \\
\hline 6 & Glycyrrhiza uralensis & Xinjiang & CCBAU \\
\hline $017 \mathrm{~A}$ & Sophora alopecuroides & Xinjiang & CCBAU \\
\hline $6-2$ & Glycyrrhiza uralensis & Xinjiang & CCBAU \\
\hline 032B & Caragana polourensis & Xinjiang & CCBAU \\
\hline $060 \mathrm{~A}$ & Halimodendron holodendron & Xinjiang & CCBAU \\
\hline $016 \mathrm{Bm}$ & Swainsonia salsula & Xinjiang & CCBAU \\
\hline $005 B$ & Sophora alopecuroides & Xinjiang & CCBAU \\
\hline 009B & Glycine $\max$ & Xinjiang & CCBAU \\
\hline $91 \times 01$ & Glycine $\max$ & Xinjiang & CCBAU \\
\hline $91 \times 05$ & Sophora alopecuroides & & \\
\hline $91 \times 07$ & Sophora alopecuroides & Xinjiang & CCBAU \\
\hline $91 \times 72$ & Sophora alopecuroides & Xinjiang & CCBAU \\
\hline $91 \times 09$ & Sophora alopecuroides & Xinjiang & CCBAU \\
\hline $91 \times 10$ & Halimodendron holodendron & Xinjiang & CCBAU \\
\hline $91 \mathrm{X} 11$ & Caragana plourensis & Xinjiang & CCBAU \\
\hline $91 \times 13$ & Glycyrrhiza sp. & Xinjiang & CCBAU \\
\hline \multicolumn{4}{|l|}{ Other strains } \\
\hline $91 \times 17$ & Sophora alopecuroides & Xinjiang & CCBAU \\
\hline $\mathrm{X} 93$ & Sophora alopecuroides & Tibet & CCBAU \\
\hline G171 & Sophora alopecuroides & Xinjiang & CCBAU \\
\hline
\end{tabular}

${ }^{a}$ Heilongiang, Huberi, Nanjing, Liaoning, Henan, and Xinjiang are regions of the People's Republic of China.

${ }^{b}$ NZP, Division of Scientific and Industrial Research. Palmerston North. New Zealand; CCBAU, Culture Collection of Beijing Agricultural University, Beijing, People's Republic of China; USDA, Beltsville Rhizobium Culture Collection, Beltsville Agricutural Research Center, Beltsville, Md.; CNPBS, Centro Nacional de Pesquisa em Biologia do Solo, Seropedica, Rio de Janeiro, Brazil; HAMBI, Culture Collection of the Department of Microbiology, University of Helsinki, Helsinki. Finland; SFRI, Soil and Fertilizer Research Institute, Chinese Academy of Agricultural Science, Beijing, Peolple's Republic of China. 


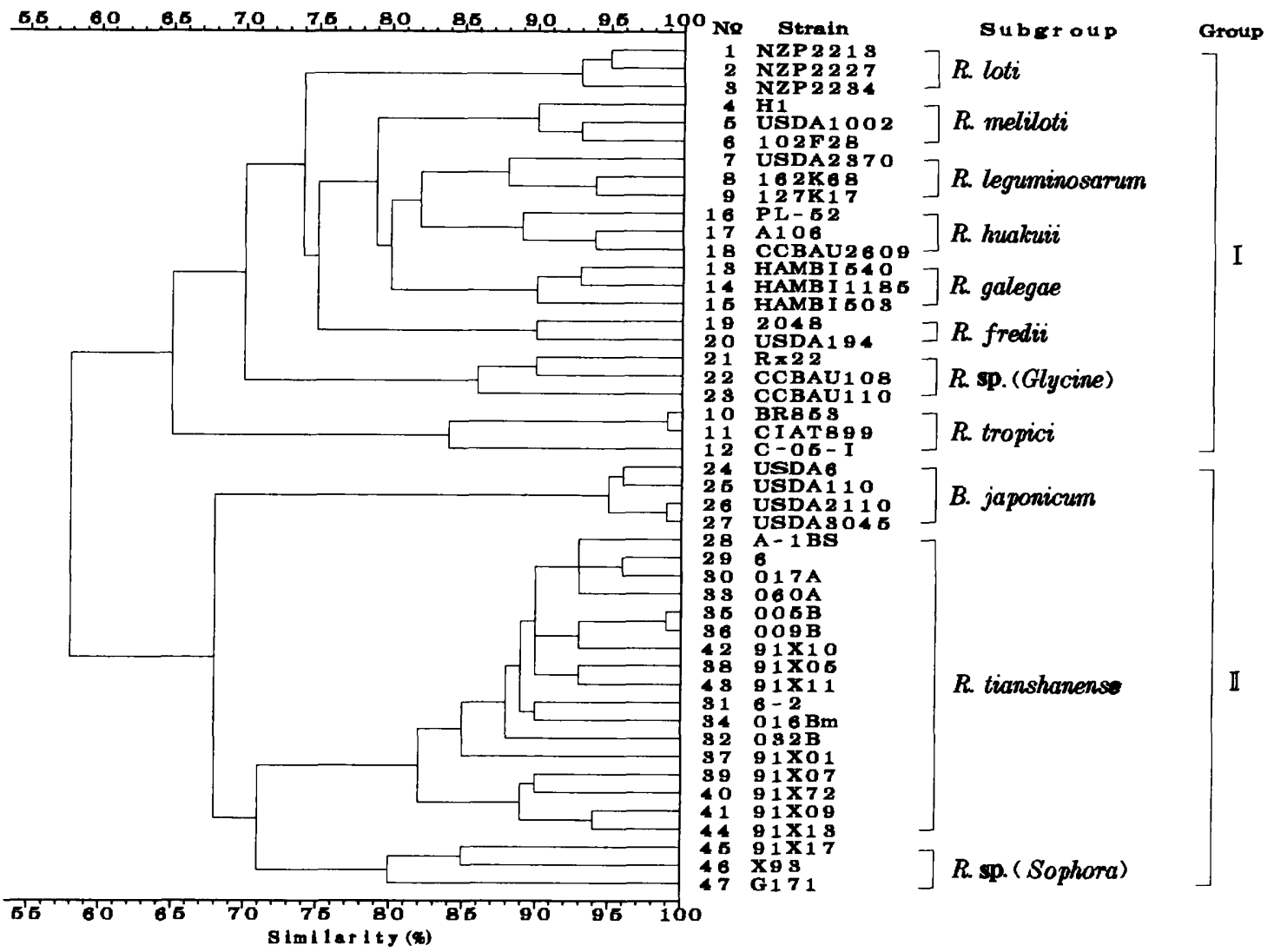

FIG. 1. Dendrogram obtained from a cluster analysis of 148 phenotypic characteristics, showing the relationships among $R$. tianshanense and related species.

previously described Rhizobium species. However, all of the moderately and slowly growing rhizobia (which we call mesogrowing rhizobia) isolated from certain leguminous genera, most of which were not included in the book The Leguminosae (1), belonged to a unique group whose members were closely related and could be clearly distinguished from either the genus Rhizobium or the genus Bradyrhizobium (3). Later, we obtained more meso-growing isolates from the same host plants growing in Xinjiang and compared these new isolates with strains belonging to previously described species by performing numerical taxonomy, DNA base composition, DNA-DNA hybridization, partial 16S rRNA gene sequencing, megaplasmid profile, and cross-inoculation analyses. In this paper we described the results of these studies and describe a new species, Rhizobium tianshanensis.

\section{MATERIALS AND METHODS}

Bacterial strains. The strains which we studied are listed in Table 1. We used 48 strains, including 17 meso-growing and 3 fast-growing rhizobia isolated from legumes growing in the Xinjiang region of the People's Republic of China and 28 reference strains. The purity of each culture was verified by repeatedly streaking single-colony isolates on plates containing YMA (24) and then reinoculating pure cultures onto the host plants. All of the strains were maintained by routine subculturing on YMA slopes or were suspended in $20 \%$ glycerol at $-30^{\circ} \mathrm{C}$.

All $R$. tianshanense strains were isolated from plants growing in the Xinjiang region of northwestern People's Republic of China. The climate in this area is a typical continental climate, with low rainfall, an evaporation potential that is much higher than the amount of precipitation received, and a wide variation in temperature. The strains were isolated in the area surrounding the Tianshan Mountains (latitude, 41.5 to $44^{\circ}$; longitude, 86 to $87.5^{\circ}$ ) at altitudes ranging from 65 to $1,100 \mathrm{~m}$. The soil in this area is a saline alkaline desert soil $(\mathrm{pH} 8.0)$. The average temperature fluctuates from -14 to $25.7^{\circ} \mathrm{C}$ during the year. The hosts of the strains are Glycyrrhiza uralensis, Glycyrrhiza pallidiflora, Sophora alopecuroides, Swainsonia salsula, Halimodendron holodendron, Caragana polourensis, and Glycine max. All of these legumes are wild plants used for Chinese medicine or for green manure, and all of them except Glycine max grow well in saline alkaline soil and are very resistant to drought.

Methods used for systematic testing. A numerical taxonomy analysis of phenotypic characteristics was performed by using the methods described previously (2). Coding of traits, calculation of similarity values by using the $S_{\mathrm{sm}}$ formula, clustering by the unweighted pair group method using arithmetic averages, and determining the center strains of groups were all performed as described by Sneath and Sokal (22).

DNA base compositions were determined by the thermal melting profile method (5), and Escherichia coli K-12 was included as a standard. Levels of DNA-DNA hybridization were determined spectrophotometrically by measuring the initial rate of reassociation, and the levels of homology were determined by using the methods of De Ley et al. (6).

The following phenotypic characteristics were used in the numerical taxonomy analysis: utilization of D-tagatose, sodium oxalate, arabitol, D-xylose, maltose, raffinose, glycogen, sodium citrate, dextrin, lactose, sodium formate, D- $(+)$ melezitose, salicin, D-arabinose, D-mannose, melibiose, fumaric acid, DL-malic acid, D-galactose, L-sorbitol, D-amygdalin, sodium tartrate, D-fucose, erythritol, fructose, ferulic acid, sodium succinate, syringic acid, inositol, inulin, glucose, L-arabinose, sodium hippurate, calcium malonate, sodium pyruvate, D-sorbitol, L-(+)-rhamnose, dulcitol, soluble starch, vanillic acid, $p$-hydroxybenzoic acid, $\alpha$-methyl-D- $(+)$-glucoside, L-glutamic acid, DL-proline, L-arginine, L-histidine, and $\mathrm{L}$-threonine as sole carbon sources; utilization of hypoxanthine, $\mathrm{L}$-isoleucine, L-phenylalanine, DL-alanine, L-valine, glycine, DL-ornithine, L-histidine, DL-proline, L-tyrosine, D-glutamic acid, L-methionine, L-(+)-aspartic acid, L-glutamic acid, L-arginine, L-leucine, D-valine, L-cystidine, L-threonine, L-serine, and Dhistidine as sole nitrogen sources; resistance to the antibiotics polymyxin B (100, 50 , and $\left.5 \mu \mathrm{g} \mathrm{ml}^{-1}\right)$, kanamycin $\left(50\right.$ and $\left.5 \mu \mathrm{g} \mathrm{ml}^{-1}\right)$, erythromycin $(300,100,50$, and $\left.5 \mu \mathrm{g} \mathrm{ml}^{-1}\right)$, ampicillin $\left(100,50\right.$, and $\left.5 \mu \mathrm{g} \mathrm{ml}^{-1}\right)$, bacitracin $(300,100,50$, and $\left.5 \mu \mathrm{g} \mathrm{ml}^{-1}\right)$, tetracycline $\left(300,100,50\right.$, and $\left.5 \mu \mathrm{g} \mathrm{ml}^{-1}\right)$, doxycycline $(100,50$, and $5 \mu \mathrm{g} \mathrm{ml}^{-1}$ ), qianglimycin $\left(5 \mu \mathrm{g} \mathrm{ml}^{-1}\right)$, streptomycin (50 and $5 \mu \mathrm{g} \mathrm{ml}^{-1}$ ), auremycin $\left(300,100,50\right.$, and $\left.5 \mu \mathrm{g} \mathrm{ml}^{-1}\right)$, and chloramphenicol $(300,100,50$, and $5 \mu \mathrm{g} \mathrm{ml}^{-1}$ ); growth in YMA containing 1.0, 1.5, 2.0, 2.5, 3.0, 3.5, 4.0, 4.5, and $5.0 \% \mathrm{NaCl}$; growth in YMA containing $0.1 \%$ acridine chlorohydrate, $0.1 \%$ malachite green, $0.1 \%$ methyl green, $0.1 \%$ bismarck brown, $0.1 \%$ bromophenol blue, $0.1 \%$ Congo red, $0.1 \%$ cotton red, $0.1 \%$ neutral red, $0.1 \%$ erythrosin $\mathrm{B}$, $0.1 \%$ bromothymol blue, $0.1 \%$ Giemsa stain, $0.1 \%$ picrocarmine, $0.1 \%$ bromocresol purple, $0.1 \%$ sodium deoxycholate, and $0.1 \%$ sodium nitrite; reduction of 
TABLE 2. Generation times, DNA G $+\mathrm{C}$ contents, and levels of DNA relatedness of meso-growing strains obtained from the Xinjiang region

\begin{tabular}{|c|c|c|c|c|c|}
\hline \multirow{2}{*}{ Species } & \multirow{2}{*}{ Strain } & \multirow{2}{*}{$\begin{array}{l}\text { Generation } \\
\text { time }(\mathrm{h})\end{array}$} & \multirow{2}{*}{$\begin{array}{c}\text { DNA G+C content } \\
(\mathrm{mol} \%)\end{array}$} & \multicolumn{2}{|c|}{$\%$ DNA relatedness to: } \\
\hline & & & & Strain 6 & Strain A-1BS \\
\hline \multirow[t]{16}{*}{ R. tianshanense } & $A-1 B S^{T}$ & 5 & 61.0 & 79.7 & 100 \\
\hline & 6 & 6 & 63.0 & 100 & 79.7 \\
\hline & 017A & 7 & 59.0 & 88.6 & 80.5 \\
\hline & $6-2$ & 6 & 63.0 & 89.7 & 88.5 \\
\hline & 032B & 9 & $\mathrm{ND}^{a}$ & 76.8 & 86.6 \\
\hline & $060 \mathrm{~A}$ & 7 & 62.0 & 74.6 & 92.7 \\
\hline & 016Bm & 9 & 61.0 & 69.6 & 82.4 \\
\hline & 005B & 5 & 63.0 & 75.3 & 75.5 \\
\hline & 009B & 10 & 59.0 & 89.2 & 80.1 \\
\hline & $91 \times 01$ & 13.5 & ND & 101.4 & 97.1 \\
\hline & $91 \times 05$ & 15.4 & ND & 90.7 & 100.4 \\
\hline & $91 \times 07$ & 5 & ND & 78.0 & 78.4 \\
\hline & $91 \times 09$ & 13 & ND & 79.0 & 88.4 \\
\hline & $91 \times 10$ & 11 & ND & 100.0 & 85.2 \\
\hline & $91 X 11$ & 14 & ND & 78.5 & 77.0 \\
\hline & $91 \times 13$ & 8 & ND & 100.0 & 88.3 \\
\hline Rhizobium sp. (Sophora) & $91 \times 17$ & 1.6 & ND & 60.3 & 65.4 \\
\hline Azorhizobium caulinodans & ORS571 ${ }^{\mathrm{T}}$ & & & 33.4 & 2.6 \\
\hline Bradyrhizobium japonicum & USDA $6^{\mathrm{T}}$ & & & 39.1 & 14.8 \\
\hline R. fredii & 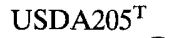 & & & 22.8 & 30.6 \\
\hline R. galegae & 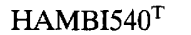 & & & ND & 44.2 \\
\hline R. huakuii & CCBAU $2609^{\mathrm{T}}$ & & & 31.5 & 63.5 \\
\hline R. leguminosarum & USDA $2370^{\mathrm{T}}$ & & & 8.3 & 6.5 \\
\hline R. loti & ATCC $33669^{\mathrm{T}}$ & & & 33.9 & 40.3 \\
\hline R. meliloti & USDA $1002^{\mathrm{T}}$ & & & 22.4 & 18.5 \\
\hline R. tropici & CIAT $899^{\mathrm{T}}$ & & & 15.6 & 45.7 \\
\hline
\end{tabular}

${ }^{a} \mathrm{ND}$, not determined.

nitrate, methylene blue, and nile blue; production of 3-keto-lactose; growth at 4 , $10,37,40,45$, and $50^{\circ} \mathrm{C}$; growth at $\mathrm{pH} 9.0,10$, and 11 ; litmus milk reaction; acid or alkali production in YMA; oxidase, catalase, L-phenylalanine deaminase, and urease production; and the presence of peritrichous cells or polar flagella.

Partial 16S rRNA gene sequencing. The method for partially sequencing $16 \mathrm{~S}$ rRNA by the PCR developed by Young et al. (29) was used to analyze the 16S rRNA genes of strain A-1BS ${ }^{\mathrm{T}}$ (T $=$ type strain) and $R$. huakuii CCBAU2609 ${ }^{\mathrm{T}}$. Two primers, Y1 (5'-TGGCTCAGAACGAACGCTGGCGGC-3') and Y2 (5'CCCACTGCTGCCTCCCGTAGGAGT-3'), were synthesized and used to amplify ribosomal DNAs.

Genomic DNAs from strain A-1BS ${ }^{\mathrm{T}}$ and $R$. huakuii CCBAU $2609^{\mathrm{T}}$ provided the templates from which a 260-bp segment of the 16S rRNA gene was amplified by PCR as described by Young et al. (29). Then this segment was cloned in phage M13, and single-stranded DNA was extracted as described by Sambrook et al. (18). The sequence of this fragment was determined by using a model ABI-370A DNA sequencer and a dye primer cycle sequencing kit, -21M13, as recommended by the manufacturer.

The sequences of strains A-1BS ${ }^{\mathrm{T}}$ and $\mathrm{CCBAU} 2609^{\mathrm{T}}$ were compared with previously published data for previously described rhizobial species $(26,29)$ by using the methods of Young et al. (29). Genetic distances $(D)$ were calculated by using the formula $D=N / T$, where $N$ is the number of nucleotide substitutions and $T$ is the total number of nucleotides. Then, a phylogenetic tree was constructed by the neighbor-joining method (17) by using $E$. coli as the root organism. Young et al. (29) omitted the nucleotides from position 26 to position 41 in their calculations of genetic distances since the number of nucleotides in this fragment varied among strains. However, in this study we omitted only the gap-containing positions for the two strains compared from our calculations.

Infection properties. Inoculation tests were performed by using the methods of Vincent (24), with some modifications. The temperature in the greenhouse was kept at $28^{\circ} \mathrm{C}$ during the day and at $12^{\circ} \mathrm{C}$ at night, and we illuminated our plants with 10,000 to $20,000 \mathrm{~lx}$ for $14 \mathrm{~h}$ per day.

Megaplasmid profile analysis. The method of Eckhardt (9) was used to determine the plasmid profile of each strain. The bacteria were lysed by adding lysozyme and sodium dodecyl sulfate to each sample well, and the products were separated by electrophoresis on a $0.6 \%$ agarose gel.

\section{RESULTS AND DISCUSSION}

Numerical classification. A total of 47 strains were analyzed by using 148 characteristics. The results of our cluster analysis performed by the unweighted pair group method using arith- metic averages are shown as a dendrogram in Fig. 1. The 47 strains which we examined were divided into two large groups, groups I and II, at a similarity level of more than $63 \%$. Group I included all of the fast-growing reference strains and was divided into eight subgroups at a similarity level of $82 \%$; these subgroups corresponded to eight previously described species, $R$. loti, $R$. meliloti, $R$. leguminosarum, $R$. huakuii, $R$ galegae, $R$. fredii, $R$. tropici, and Rhizobium sp. (Glycine), for which the name Sinorhizobium xinjiangensis has been proposed (4).

Group II was divided into three subgroups at a similarity level of more than $80 \%$. These subgroups corresponded to Bradyrhizobium japonicum, $R$. tianshanense, and a small subgroup consisting of three fast-growing strains. The $R$. tianshanense subgroup contained 17 meso-growing strains that were isolated from plants growing in Xinjiang and were clearly different from either Bradyrhizobium japonicum or previously described Rhizobium species. The generation time of this meso-growing bacterium was 5 to $15 \mathrm{~h}$. $R$. tianshanense strains used L-rhamnose and erythritol as sole carbon sources, produced acid in medium containing mannitol, and had peritrichous flagella. Strain A-1BS was selected as the centrotype strain in our previous work (3) on the basis of the results of a comparison of the average levels of similarity among all members of this group (22). The last subgroup contained only three strain, 91X17, X93, and G171, which were isolated from plants growing in Xinjiang and Tibet. These organisms were isolated from nodules of Sophora alopecuroides, a plant that was a host of $R$. tianshanense, and they grew faster than $R$. tianshanense strains. The generation time of strain $91 \mathrm{X} 17$ was $1.6 \mathrm{~h}$. Additional studies will be required to determine the taxonomic position of these three strains.

DNA base composition and DNA-DNA hybridization. Table 2 shows the $\mathrm{G}+\mathrm{C}$ contents and levels of homology of the DNAs of the meso-growing rhizobia obtained from Xinjiang. 
The $\mathrm{G}+\mathrm{C}$ contents of the DNAs of these strains ranged from 59 to $63 \mathrm{~mol} \%$, values which fall into the range of values for the genus Rhizobium (14). When we examined DNA homology, the DNAs of two representative meso-growing strains, A-1BS ${ }^{\mathbf{T}}$ and 6, hybridized with the DNAs of all 17 meso-growing strains obtained from Xinjiang and with the DNAs of type or reference strains of $R$. meliloti, $R$. loti, $R$. leguminosarum, $R$. tropici, R. galegae, R. haukuii, R. fredii, Rhizobium sp. (Glycine), Azorhizobium caulinodans, and Bradyrhizobium japonicum. The levels of DNA-DNA homology for all of the meso-growing rhizobia obtained from Xinjiang were greater than $70 \%$, satisfying the criterion for the creation of a new species according to the minimal standards for the description of new genera and species of root- and stem-nodulating bacteria (11). The levels of DNA-DNA homology between members of this group and members of all other species of root- and stemnodulating bacteria ranged from 2.6 to $65.4 \%$. These results showed that the meso-growing strains obtained from Xinjiang constituted a separate DNA homology group.

Strain 91X17, representing the small group mentioned above, exhibited levels of DNA-DNA homology of 60.3 and $65.4 \%$ with strains 6 and A-1BS ${ }^{\mathrm{T}}$, respectively. These results indicate that the small subgroup might be closely related to the meso-growing strains.

The taxonomic results described above suggested that the meso-growing rhizobia obtained from Xinjiang were members of a unique group, which differed clearly from previously described Bradyrhizobium and Rhizobium species.

Partial 16S rRNA gene sequencing. An alignment of the sequences of strain $\mathrm{A}-1 \mathrm{BS}^{\mathrm{T}}$ and its relatives $(26,30)$ is shown in Fig. 2. The cloned 260-base fragment which we used corresponds to positions 44 to 337 in the E. coli $16 \mathrm{~S}$ rRNA sequence.

Genetic distances based on the sequences in Fig. 2 are shown in Table 3, and a phylogenetic tree is shown in Fig. 3.

Young (28) demonstrated that for most Rhizobium species, phylogenetic positions based on partial 16S rRNA gene sequence data were very similar to phylogenetic positions based on complete sequence data. The only exception was $R$. galegae. $R$. galegae was very closely related to $R$. huakuii and $R$. loti on the basis of partial sequence data, but it formed a separate lineage when the complete sequences were compared (26).

In Fig. 3, the meso-growing strains, $R$. huakuii, $R$. loti, and $R$. galegae form a closely related phylogenetic branch with genetic distances of 0.8 to $2.7 \%$. Another branch consisted of $R$. meliloti and $R$. leguminosarum (genetic distance, 2.7\%). The genetic distances between these two branches are 5.4 to $6.9 \%$.

Many phylogenetic analyses of the family Rhizobiaceae have shown that the genus Rhizobium should be split into several genera, but it has been proposed that more studies are needed before a change can be made $(26,28)$. Thus, the meso-growing rhizobia examined in this study should be treated as members of the genus Rhizobium, although this taxon is rather far from the type species of the genus, $R$. leguminosarum on the phylogenetic tree. An analysis of the complete sequence of the $16 \mathrm{~S}$ rRNA of $R$. tianshanense might clarify the phylogenetic position of this organism.

Infection properties. Strain A-1BS ${ }^{\mathrm{T}}$, a representative of $R$. tianshanense, was examined to determine its symbiotic relationship with the original host plants and possible symbiotic relationships with other plants. Our results indicated that strain A-1BS ${ }^{\mathbf{T}}$ could nodulate all of the original host species of $R$. tianshanense strains but did not nodulate Pisum sativum, Medicago sativa, Phaseolus vulgaris, Trifolium repens, Lotus corniculatus, Leucaena leucocephala, Macroptilium atropurpureum, Vigna unguiculata, and Astragalus sinicus. This means

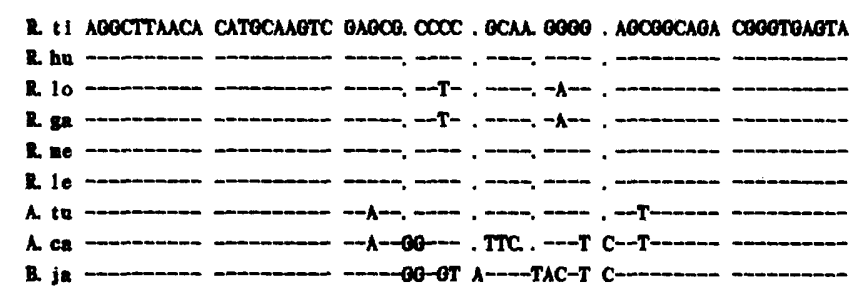

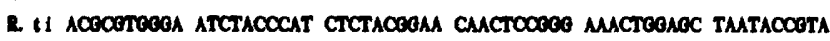

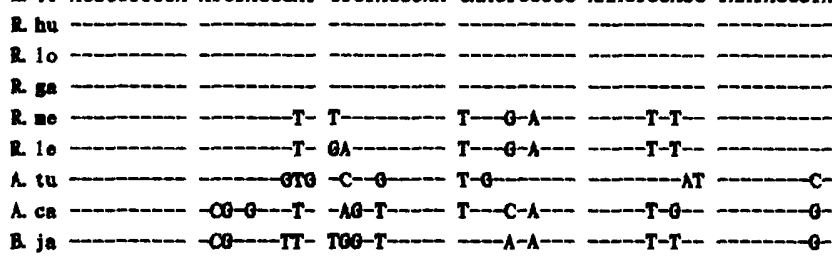

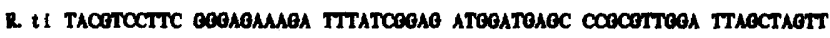

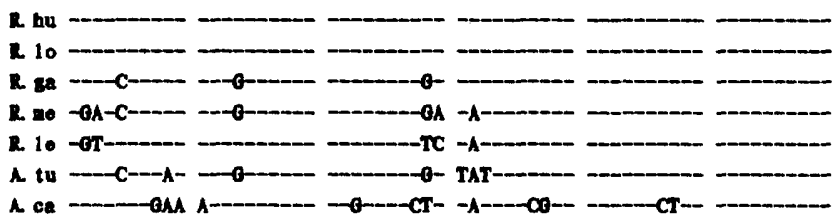

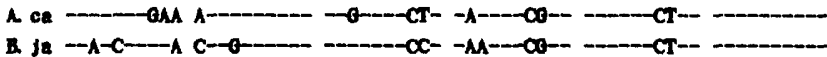

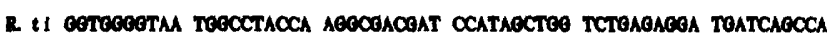

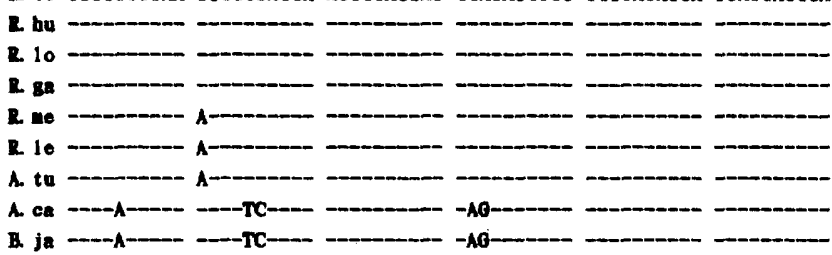

L. el cattogonct gagacicooc cocus

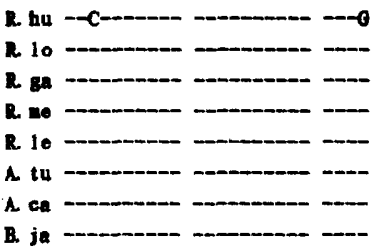

FIG. 2. Alignment of sequences of parts of the 16S rRNA genes of $R$ tianshanense A-1BS ${ }^{\mathrm{T}}$ (R. ti), $R$. huakuii CCBAU $2609^{\mathrm{T}}$ (R. hu), $R$. loti LMG6125 (R. lo) (26), R. galegae LMG6214 (R. ga) (26). R. meliloti NZP4017 (R. me) (30), R. leguminosarum bv. phaseoli 8002 (R. le) (30), Agrobacterium tumefaciens DSM30105 (A. tu) (12), Azorhizobium caulinodans ORS571 (A. ca) (30), and Bradyrhizobium japonicum USDA31 (B. ja.) (30). Dashes indicate that nucleotides are identical to the nucleotides in the $R$. tianshanense sequence, and dots indicate alignment gaps.

that the members of $R$. tianshanense formed a single crossinoculation group.

Megaplasmid profile analysis. Frequently, the nodulation and nitrogen-fixing genes are located in megaplasmids in Rhizobium strains and in the chromosome in Bradyrhizobium strains. In our studies, all fast-growing strains contained one or more plasmids larger than $20 \mathrm{~kb}$, while all meso-growing strains did not contain plasmids.

On the basis of the results of numerical taxonomy, DNA base composition, DNA-DNA hybridization, and cross-inoculation analyses, as well as the results of 16S rRNA gene sequencing, we propose that the meso-growing rhizobia obtained from Xinjiang should be assigned to a new species, Rhizobium tianshanense. 
TABLE 3. Distance matrix for R. tianshanense A-1BS ${ }^{\mathrm{T}}$ and its relatives calculated from the alignment of 16S rRNA gene sequence shown in Fig. 2

\begin{tabular}{|c|c|c|c|c|c|c|c|c|c|}
\hline \multirow[b]{2}{*}{ Strain } & \multicolumn{9}{|c|}{ No. of nucleotide differences or evolutionary distance } \\
\hline & 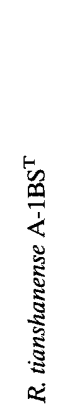 & 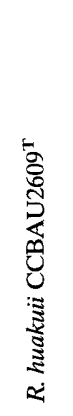 & 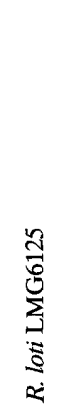 & 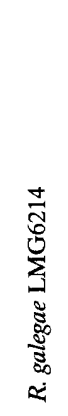 & 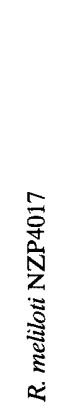 & 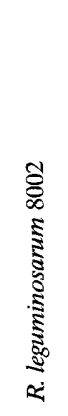 & 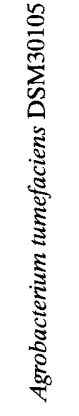 & 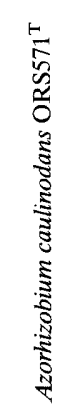 & 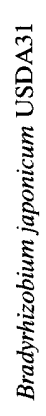 \\
\hline R. tianshanense $\mathrm{A}-1 \mathrm{BS}^{\mathrm{T}}$ & & 2 & 2 & 5 & 15 & 14 & 20 & 40 & 41 \\
\hline R. huakuii CCBAU2609 ${ }^{\mathrm{T}}$ & 0.8 & & 4 & 7 & 17 & 16 & 22 & 43 & 43 \\
\hline R. loti LMG6125 & 0.8 & 1.5 & & 3 & 17 & 16 & 22 & 42 & 41 \\
\hline R. galegae LMG6214 & 1.9 & 2.7 & 1.2 & & 14 & 18 & 19 & 43 & 39 \\
\hline R. meliloti NZP4017 & 5.8 & 6.5 & 6.5 & 5.4 & & 7 & 21 & 41 & 36 \\
\hline R. leguminosarum 8002 & 5.4 & 6.2 & 6.2 & 6.9 & 2.7 & & 24 & 37 & 40 \\
\hline Agrobacterium tumefaciens DSM30105 & 7.7 & 8.5 & 8.5 & 7.3 & 8.1 & 9.2 & & 43 & 47 \\
\hline Azorhizobium caulinodans ORS571 ${ }^{\mathrm{T}}$ & 15.2 & 16.3 & 16.0 & 16.3 & 15.6 & 14.1 & 16.3 & & 28 \\
\hline Bradyrhizobium japonicum USDA31 & 15.5 & 16.3 & 15.5 & 14.8 & 13.6 & 15.2 & 17.8 & 10.6 & \\
\hline
\end{tabular}

${ }^{a}$ The values on the upper right are the numbers of nucleotide differences, and the values on the lower left are evolutionary distances (percent).

Description of Rhizobium tianshanense sp. nov. Rhizobium tianshanense (tian. shan. en' se. M. L. adj. tianshanense, referring to the Tianshan Mountains in the Xinjiang region of the People's Republic of China, where strains were isolated). Aerobic, gram-negative, non-spore-forming rods that are 0.25 to 0.9 by 1.2 to $3.0 \mu \mathrm{m}$. Cells move by means of peritrichous flagella. Colonies on YMA are circular, opaque, and convex, have a creamy color, and are usually 1 to $2 \mathrm{~mm}$ in diameter after 5 to 7 days of incubation. The optimum growth temperature is 25 to $30^{\circ} \mathrm{C}$, and the optimum pH is 6 to 8 . Strains can grow on YMA in the presence of $1.0 \% \mathrm{NaCl}$. Some strains can grow at 4 or $10^{\circ} \mathrm{C}$. Glucose, mannitol, glycerol, xylose, fucose, erithritol, DL-proline, L-(+)-glutamic acid, and rhamnose are used as sole carbon and energy sources by all strains, and

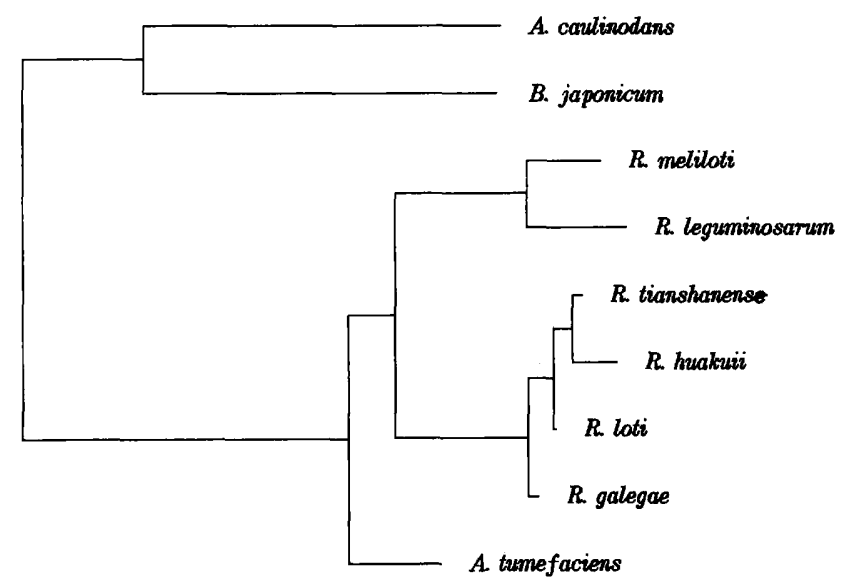

FIG. 3. Phylogenetic tree derived from the partial 16S rRNA gene sequences shown in Fig. 2 for $R$. tianshanense and its relatives. The tree was constructed by using the neighbor-joining method (17). lactose, maltose, sucrose, pyruvate, raffinose, sorbitol, fructose, mannose, arabiose, citrate, and dulcitol are used by some strains. Tagatose, galactose, melibiose, sorbose, inulin, benzoate, malate, vanillic acid, inositol, salicytol, fumarate, pyrocatechol, starch, and dextrin are not utilized. Produces an acid reaction on YMA. Ammonium salts, nitrate, and many amino acids, including glutamate, glycyl-L-leucine, norvaline, threonine, arginine, proline, and glycine, are used as sole nitrogen sources. Peptone is not utilized. No megaplasmid is observed.

The $\mathrm{G}+\mathrm{C}$ content of the DNA is 59 to $63 \mathrm{~mol} \%$.

The type strain is A-1BS (= CCBAU3306). The generation time of this strain is $5 \mathrm{~h}$, and the $\mathrm{G}+\mathrm{C}$ content of its DNA is $61 \mathrm{~mol} \%$ (as determined by the thermal denaturation method).

\section{ACKNOWLEDGMENTS}

We thank Xiaobo Wang for analyzing the plasmid profiles.

This investigation was supported by the National Natural Science Foundation of China.

\section{REFERENCES}

1. Allen, O. N., and E. A. Allen. 1981. The Leguminosae, a source book of characteristics, uses, and nodulation. The University of Wisconsin Press, Madison.

2. Chen, W. X., G. S. Li, Y. L. Qi, E. T. Wang, H. L. Yuan, and J. L. Li. 1991. Rhizobium huakuii sp. nov. isolated from the root nodules of Astragalus sinicus. Int. J. Syst. Bacteriol. 41:275-280.

3. Chen, W. X., B. H. Wu, C. H. Luo, J. L. Li, Y. H. Shi, L. Huang, and Z. Y. Wu. 1987. The survey and taxonomy of leguminous root nodule bacteria of Xinjiang Region. Sci. Agric. Sin. 20:22-27. (In Chinese).

4. Chen, W. X., G. H. Yan, and J. L. Li. 1988. Numerical taxonomic study of fast-growing soybean rhizobia and a proposal that Rhizobium fredii be assigned to Sinorhizobium gen. nov. Int. J. Syst. Bacteriol. 38:392-397.

5. De Ley, J. 1970. Reexamination of the association between melting point, buoyant density, and chemical base composition of DNA. J. Bacteriol. 101:738-754.

6. De Ley, J., H. Cattoir, and A. Reynaerts. 1970. The quantitative measurement of DNA hybridization from renaturation rates. Eur. J. Biochem. 12:133-142.

7. De Smedt, J., and J. De Ley. 1977. Intra- and intergeneric similarities of Agrobacterium ribosomal ribonucleic acid cistrons. Int. J. Syst. Bacteriol. 27:222-240.

8. Dreyfus, B., J. L. Garcia, and M. Gillis. 1988. Characterization of Azorhizo- 
bium caulinodans gen. nov., sp. nov., a stem-nodulating nitrogen-fixing bacterium isolated from Sesbania rostrata. Int. J. Syst. Bacteriol. 38:89-98.

9. Eckhardt, T. 1978. A rapid method for the identification of plasmid DNA in bacteria. Plasmid 1:584-588.

10. Gao, J. L., J. G. Sun, Y. Li, E. T. Wang, and W. X. Chen. 1994. Numerical and DNA relatedness of tropical rhizobia isolated from Hainan Province, China. Int. J. Syst. Bacteriol. 44:151-158.

11. Graham, P. H., M. J. Sadowsky, H. H. Keyser, Y. M. Barnet, R. S. Bradley, J. E. Cooper, J. De Ley, B. D. W. Jarvis, E. B. Roslycky, B. W. Strijdom, and J. P. W. Young. 1991. Proposed minimal standards for the description of new genera and species of root- and stem-nodulating bacteria. Int. J. Syst. Bacteriol. 41:582-587.

12. Jarvis, B. D. W., H. L. Downer, and J. P. W. Young. 1992. Phylogeny of fast-growing soybean-nodulating rhizobia supports synonymy of Sinorhozobium and Rhizobium and assignment to Rhizobium fredii. Int. J. Syst. Bacteriol. 42:93-96.

13. Jarvis, B. D. W., M. Gillis, and J. De Ley. 1986. Intra- and intergeneric similarities between the ribosomal ribonucleic acid cistrons of Rhizobium and Bradyrhizobium species and some related bacteria. Int. J. Syst. Bacteriol. 36:129-138.

14. Jordan, D. C. 1984. Family III. Rhizobiaceae Conn $1938,321^{\mathrm{AL}}$, p. $235-244$. In N. R. Krieg and J. G. Holt (ed.), Bergey's manual of systematic bacteriology, vol. 1. The Williams and Wilkins Co., Baltimore.

15. Lindstrom, K. 1989. Rhizobium galegae, a new species of legume root nodule bacteria. Int. J. Syst. Bacteriol. 39:365-367.

16. Martinez-Romero, E., L. Segovia, F. Martins, A. A. Franco, P. Graham, and M. A. Pardo. 1991. Rhizobium tropici, a novel species nodulating Phaseolus vulgaris L. beans and Leucaena sp. trees. Int. J. Syst. Bacteriol. 41:417-426.

17. Saito, N., and M. Nei. 1987. The neighbor-joining method: a new method for reconstructing phylogenetic trees. Mol. Biol. Evol. 4:406-425.

18. Sambrook, J., E. F. Fritsch, and T. Maniatis. 1989. Molecular cloning: a laboratory manual, 2nd ed., p. 4.21-4.43. Cold Spring Harbor Laboratory Press, Cold Spring Harbor, N.Y

19. Sawada, H., H. Ieki, H. Oyaizu, and S. Matsumoto. 1993. Proposal for rejection of Agrobacterium tumefaciens and revised descriptions for the genus
Agrobacterium and for Agrobacterium radiobacter and Agrobacterium rhizogenes. Int. J. Syst. Bacteriol. 43:694-702.

20. Scholla, M. H., and G. H. Elkan. 1984. Rhizobium fredii sp. nov., a fast-growing species that effectively nodulates soybeans. Int. J. Syst. Bacteriol. 34:484-486.

21. Segovia, L., J. P. W. Young, and E. Martinez-Romero. 1993. Reclassification of American Rhizobium leguminosarum biovar phaseoli type I strains as Rhizobium etli sp. nov. Int. J. Syst. Bacteriol. 43:374-377.

22. Sneath, P. H. A., and R. B. Sokal. 1973. Numerical taxonomy, the principles and practices of numerical classification. W. H. Freeman and Co., San Francisco.

23. Stackebrandt, E., R. G. E. Murray, and H. G. Trüper. 1988. Proteobacteria classis nov., a name for the phylogenetic taxon that includes the "purple bacteria and their relatives." Int. J. Syst. Bacteriol. 38:321-325.

24. Vincent, J. M. 1970 . A manual for the practical study of root nodule bacteria, p. 3-4. Blackwell Scientific Publications. Oxford.

25. Willems, A., and M. D. Collins. 1992. Evidence for a close genealogical relationship between Afipia, the causal organism of cat scratch disease. Bradyrhizobium japonicum and Blastobacter denitrificans. FEMS Microbiol. Lett. 96:241-246.

26. Willems, A., and M. D. Collins. 1993. Phylogenetic analysis of rhizobia and agrobacteria based on 16S rRNA gene sequences. Int. I. Syst. Bacteriol. 43:305-313.

27. Yanagi, M., and K. Yamasato. 1993. Phylogenetic analysis of the family Rhizobiaceae and related bacteria by sequencing of $16 \mathrm{~S}$ rRNA gene using PCR and DNA sequencer. FEMS Microbiol. Lett. 107:115-120.

28. Young, J. P. W. 1993. Phylogenetic classification of nitrogen-fixing organisms, p. 43-86. In C. Stacey, R. H. Burris, and H. J. Evans (ed.), Biological nitrogen fixation. Champan \& Hall, New York.

29. Young, J. P. W., H. L. Downer, and B. D. Eardly. 1991. Phylogeny of the phototrophic Rhizobium strain BTail by polymerase chain reaction-based sequencing of a 16S rRNA gene segment. J. Bacteriol. 173:2271-2277.

30. Young, J. P. W., and A. W. B. Johnston. 1989. The evolution of specificity in the legume-Rhizobium symbiosis. Tree 4:341-349. 